\title{
Pengaruh Minat Baca dan Penguasaan Kosakata terhadap Kemampuan Menulis Cerita Pendek
}

\author{
Teni Hikmatin \\ Universitas Indraprasta PGRI \\ Jalan Nangka No. 58 C/TB. Simatupang, Tanjung Barat, Jakarta Selatan 12530 \\ tenihikmatin6@gmail.com
}

\begin{abstract}
Interest in writing is generally still low. The low ability of students to write short stories is due to a lack of reading interest and low mastery of vocabulary. writing them due to lack of interest in reading and low mastery of vocabulary. The purpose of this study was to determine the effect of reading munat and vocabulary mastery on the ability to write short stories. This study uses the Survey Method. The data analysis technique used is three stages, namely Descriptive Analysis, Test Requirements for Data Analysis, and Test of Hypothesis Research. The result of the study show that: first, there is a significant effect of the Interest in Reading and Mastery of Vocabulary together with Skill in Writing Short Stories. Second,there is a significant effect of Reading Interest on the ability to write short stories. Third, there is a sginificant influence on Vocabulary Mastery on the Abilty to Write Short Stroies.
\end{abstract}

Keywords: Reading interest, mastery of Vocabulary, writing skills short story

\begin{abstract}
Abstrak
Minat menulis pada umumnya masih rendah. Rendahnya kemampuan siswa dalam menulis cerita pendek karena kurangnya minat baca dan penguasaan kosakata yang rendah. Tujuan penelitian ini untuk mengetahui pengaruh minat baca dan penguasaan kosakata terhadap kemampuan menulis cerita pendek. Penelitian ini menggunakan Metode Survey. Teknik analisis data yang digunakan ada tiga tahap, yaitu Analisis Deskriptif, Uji Persyaratan Analisis Data, dan Uji Hipotesis Penelitian. Hasil penelitian menunjukkan bahwa: pertama, terdapat pengaruh yang signifikan Minat Baca dan Penguasaan Kosakata secara bersama-sama terhadap Kemampuan Menulis Cerita Pendek. Kedua, terdapat pengaruh yang signifikan Minat Baca terhadap Kemampuan Menulis Cerita Pendek. Ketiga, terdapat pengaruh yang signifikan Penguasaan Kosakata terhadap Kemampuan Menulis Cerita Pendek
\end{abstract}

Kata Kunci: minat baca, penguasaan kosakata, kemampuan menulis cerita pendek

\section{PENDAHULUAN}

Ruang lingkup mata pelajaran Bahasa Indonesia di Sekolah Menengah Pertama mencakup kemampuan berbahasa dan bersastra yang meliputi empat aspek keterampilan, yaitu mendengarkan, berbicara, membaca, dan menulis. Keempat keterampilan tersebut diarahkan untuk meningkatkan kemampuan siswa berkomunikasi secara lisan maupun tulisan.

Kemampuan berbahasa Indonesia secara lisan antara lain, mampu menyampaikan informasi aktual secara emosional, menyatakan sikap intelektual, serta menyatakan sikap moral. Kemampuan berbahasa Indonesia secara tertulis diarahkan agar siswa memiliki kegemaran menulis sehingga mampu meningkatkan 
pengetahuannya, menyampaikan informasi aktual, menyatakan sikap intelektual, menyatakan sikap moral dan mampu memanfaatkannya kehidupan sehari-hari. Oleh sebab itu manusia dituntut untuk mencari ilmu supaya mudah dalam bersosialisasi dan mengerti bahasa terutama dalam menulis.

Namun kemampuan menulis dianggap sebagai kemampuan yang paling sulit. Menurut Nurgiyantoro (2001 : 296), menulis merupakan kemampuan yang lebih sulit dikuasai dibandingkan tiga kemampuan lain yaitu menyimak, berbicara, dan membaca. Hal itu disebabkan keterampilan menulis memerlukan penguasaan berbagai unsur kebahasaan dan di luar bahasa itu sendiri yang akan menjadi isi karangan atau tulisan. Pembelajaran keterampilan menulis memiliki berbagai macam bentuk, diantaranya adalah keterampilan menulis cerita pendek. Keterampilan menulis cerita pendek dapat diperoleh dari membaca. Banyaknya bacaan yang dibaca dipengaruhi oleh minat baca. Selain itu, penguasaan kosakata diperlukan dalam kemampuan menulis cerita pendek. Dalam tulisan diperlukan kosakata yang tepat agar orang lain mengerti apa yang dimaksudkannya. Semakin banyak bacaan yang dibaca, semakin banyak pula kosakata yang dimiliki. Kegiatan membaca dapat bermakna dan berkualitas apabila didorong oleh minat baca yang tinggi. Minat baca yang rendah diduga sebagai pemicu rendahnya penguasaan kosakata.

Henry Guntur Tarigan (2011 : 2) mengatakan bahwa kualitas keterampilan berbahasa seseorang jelas bergantung kepada kuantitas dan kualitas kosakata yang dimilikinya. Penguasaan terhadap kosakata sangat diperlukan oleh setiap pemakai bahasa. Kosa kata pada prinsipnya dipelajari siswa bertujuan untuk dapat menyimak, berbicara, membaca, dan menulis dengan baik. Oleh karena itu, siswa membutuhkan suatu sistem untuk menerima, menyimpan, dan mendapatkan kembali kosakata itu setiap saat. Siswa haruslah mempunyai rasa ingin tahu yang mendalam mengenai kosakata dan memperhatikan secara teliti bagaimana kosa kata dipergunakan dalam kalimat dan kosakata itu dibentuk . Kekurangmampuan siswa dalam mengungkapkan gagasan atau idenya secara tertulis, salah satunya disebabkan oleh kurangnya penguasaan kosakata. Dengan perbendaharaan kata yang cukup, siswa lebih mudah mengungkapkan segala pendapat, gagasan, pikiran, dan perasaannya kepada orang lain, salah satunya dengan menulis cerita pendek.

Di masa sekarang kreatifitas seorang pendidik sangat perlu untuk ditingkatkan, agar peserta didk dapat belajar lebih efektif dan menyenangkan. Dapat dipastikan para pendidik diminta agar lebih profesional dalam menjalankan tugasnya sebagai pendidik. Upaya maksimal para pendidik guna meningkatkan kemampuan menulis cerita pendek pada siswa di Sekolah Menengah Pertama Swasta Kabupaten Bogor, dengan dilandasi minat baca dan penguasaan kosakata, tampaknya masih belum menjadi kenyataan. Sebab, berdasarkan data-data yang penulis peroleh dari siswa-siswi kelas IX Sekolah Menengah Pertama Swasta di Kabupaten Bogor, hampir seluruhnya kemampuan menulisnya masih lemah. Kelemahan menulis mereka, dapat saja diakibatkan oleh ketidak profesionalan sang guru dalam mengampu mata pelajaran bahasa Indonesia, keterampilan menulis mereka kurang ditingkatkan, alokasi waktu untuk kegiatan membaca masih seperti biasa, aktivasi komunikasi dengan memperhatikan ketiga unsur itu belum diseriuskan, dan lain sebagainya. Kemampuan siswa dalam menuangkan ide atau

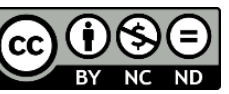

Creative Commons Attribution-NonCommercial-NoDerivatives 4.0 International License 
gagasan dalam bentuk tulisan masih kurang. Siswa lebih suka berbicara langsung atau menceritakan sesuatu. Siswa kesulitan menuangkan ide-ide atau gagasan untuk menulis cerita pendek. Dan untuk meningkatkan kemampuan menulis cerita pendek pada siswa, kita harus mengetahui faktor apa yang paling mempengaruhi kemampuan menulis cerita pendek ini.

Menurut Zain dalam Milman Yusdi (2010:10) mengartikan bahwa kemampuan adalah kesanggupan, kecakapan, kekuatan kita berusaha dengan diri sendiri. Sementara itu, Robbin (2007:57) kemampuan berarti kapasitas seseoang individu untuk melakukan beragam tugas dalam suatu pekerjaan.

Menulis merupakan bentuk manisfestasi dari keterampilan berbahasa yang paling akhir yang harus dikuasai oleh peserta didik. Hal ini sesuai dengan pendapat Nurgiyantoro (2001:256) yang menyatakan bahwa aktivitas menulis merupakan suatu bentuk manifestasi dan keterampilan berbahasa paling akhir dikuasai setelah menyimak, berbicara, dan membaca. Suparno (2004:13) berpendapat bahwa menulis merupakan sebuah proses kreatif menuangkan gagasan dalam bentuk bahasa tulis untuk tujuan, misalnya memberitahu, meyakinkan, atau memghibur. Hasil dari proses kreatif ini bisa disebut denghan istilah karangan atau tulisan.

Cerpen merupakan akronim dari cerita pendek. Cerita dalam KBBI (2001:210) adalah tuturan yang membentangkan bagaimana terjadinya suatu hal. Menurut Nurgiyantoro (2007: 10) cerpen adalah cerita yang pendek. Secara etimologis cerpen pada dasarnya adalah karya fiksi atau sesuatu yang dikontruksikan, ditemukan, dibuat, atau dibuat-buat. Hal itu berarti bahwa cerpen tidak terlepas dari fakta. Fiksi yang merujuk pada rekaan dalam cerpen terdapat dalam kontruksi fisiknya. Sementara fakta yang merujuk pada realita cerpen terkandung dalam temanya. Dengan demikian cerpen dapat disusun berdasarkan fakta yang dialami atau dirasakan penulisnya.

Minat berkaitan dengan perasaan suka atau senang dari seseorang terhadap sesuatu objek. Hal ini seperti dikemukakan oleh Slameto (2003:57) yang menyatakan bahwa minat adalah kecenderungan yang tetap untuk memperhatikan dan mengenang beberapa kegiatan. Djaali (2008: 12) berpendapat bahwa minat pada dasarnya merupakan penerimaan akan suatu hubungan antara diri sendiri dengan sesuatu di luar diri. Dari beberapa pendapat para ahli di atas dapat disimpulkan bahwa minat merupakan kecenderungan seseorang yang ditandai dengan rasa senang atau ketertarikan pada objek tertentu dan keinginan untuk terlibat dalam aktivitas objek tertentu. Sehingga mengakibatkan seseorang memiliki keinginan untuk terlibat secara langsung dalam suatu objek atau aktivitas tertentu, karena dirasakan bermakna bagi dirinya dan ada harapan yang dituju.

Di dalam penelitian ini, minat dilekatkan dengan aktivitas membaca. Membaca adalah proses mengenal kata, memadukan arti kata dalam kalimat dan struktur bacaan. Menurut Kamus Besar Bahasa Indonesia (2001:83), membaca adalah mengeja atau melafalkan apa yang ditulis. Sementara menurut Tarigan (2008:7), membaca adalah suatu proses yang dilakukan untuk memperoleh pesan melalui bahasa tulis. Hal itu sejalan dengan Kridalaksana (2007:3), menurutnya membaca adalah proses memahami isi atau makna pesan yang hendak disampaikan penulis dalam bentuk lambang-lambang atau tulisan, sehingga diperoleh pemahaman terhadap bacaan. Jadi, minat membaca adalah tingkat kesenangan yang 
kuat dari seseorang dalam melakukan kegiatan membaca karena kegiatan tersebut menyenangkan dan memberi nilai positif padanya

Berdasarkan KBBI (2001:597) kosakata adalah perbendaharaan kata atau banyaknya kata-kata yang dimiliki suatu bahasa. Kekayaan kosakata itu berada dalam ingatannya, yang segera akan menimbulkan reaksi bila didengar atau dibaca. Chaer (2011:131), Kosakata bahasa Indonesia adalah semua kata yang terdapat dalam bahasa Indonesia. Kosakata seseorang didefinisikan sebagai himpunan kata. Kosakata juga dapat diartikan sebagai himpunan kata yang diketahui oleh seseorang, atau merupakan bagian dari kata yang dimengerti oleh orang tersebut atau semua kata-kata yang memungkinkan akan digunakan oleh orang tersebut untuk menyusun kalimat baru.

Menurut Tarigan (2011:78) penguasaan kosakata adalah kegiatan menguasai atau keterampilan memahami dan menggunakan kata-kata yang terdapat dalam suatu bahasa, baik bahasa lisan maupun bahasa tulisan. Penguasaan kosakata dibagi menjadi dua, yaitu penguasaan kosakata ekspresif dan reseptif. Penguasaan kosakata ekspresif digunakan untuk keperluan bicara dan menulis, sedangkan penguasaan kosakata reseptif digunakan untuk keperluan menyimak dan membaca.

Selanjutnya, hasil penelitian Staehr (2008:144) menujukan bahwa penguasaan kosakata memiliki hubungan yang signifikan dengan keempat keterampilan berbahasa yakni menyimak, membaca, dan menulis. Penguasaan kosakata yang baik akan dapat memberikan kontribusi banyak dalam kegiatan berbahasa salah satunya penulisan cerita pendek

\section{METODE}

Penelitian ini menggunakan metode survey. Penelitian ini dilakukan untuk memperoleh data dan fakta berdasarkan pengujian variabel-variabel penelitian. Penelitian ini merupakan penelitian deskriptif korelasional. Variabel dilihat apa adanya tanpa manipulasi. Subjek penelitian ini adalah siswa SMP Wira Buana dan SMP Islam Alfalah tahun pelajaran 2018-2019. Populasi terjangkau dalam penelitian adalah jumlah keseluruhan sebanyak 560 siswa. Dari populasi terjangkau diatas, diambil secara random sampling sebanyak 15\% sebagai sampel penelitian. Dengan demikian, jumlah sampel yang sebanyak $560 \times 15 \%=84$ orang responden. Penetapan 84orang siswa sebagai responden/ ditetapkan sampel ini menggunakan two-stage-random-sampling, yaitu teknik pengambilan sampel dari semua anggota populasi dilakukan secara acak tanpa memperhatikan strata yang ada dalam populasi tersebut.

Pengumpulan data dalam penelitian ini dilakukan dengan menempuh mekanisme penjadwalan hasil tes minat baca, tes penguasaan kosakata, dan tes menulis cerita pendek. Adapun teknik pengumpulan data tersebut dilakukan dengan langkah, sebagai berikut : 1) Mengadakan tes minat baca dan tes penguasaan kosakata dengan memberikan soal berbentuk angket dan pilihan ganda (multiple choice test) yangb telah disediakan oleh peneliti; 2) Mengadakan tes kemampuan menulis cerita pendek; Memeriksa seluruh tes yang telah diberikan kepada para

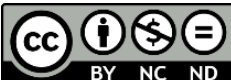

Creative Commons Attribution-NonCommercial-NoDerivatives 4.0 International License 
responden; 3) Memberi nilai seluruh tes siswa yang selanjutnya nilai-nilai tersebut dijadikan data tabulasi untuk ketiga variabel dalam penelitian ini.

\section{HASIL DAN PEMBAHASAN}

Hasil perhitungan dan pengujian bisa dilihat pada tabel di bawah ini:

Tabel 1. Hasil Perhitungan Pengujian Koefisien Korelasi Ganda Variabel $\mathrm{X}_{1}$ dan $\mathrm{X}_{2}$ terhadap $\mathrm{Y}$

\begin{tabular}{|c|c|c|c|c|}
\hline \multicolumn{5}{|c|}{ Model Summary } \\
\hline Model & $\mathrm{R}$ & R Square & Adjusted R Square & $\begin{array}{l}\text { Std. Error of the } \\
\text { Estimate }\end{array}$ \\
\hline 1 & $.520^{\mathrm{a}}$ & .270 & .252 & 6.626 \\
\hline
\end{tabular}

Tabel 2. Hasil Perhitungan Pengujian Signifikansi Koefisien Regresi Variabel $\mathrm{X}_{1}$ dan $\mathrm{X}_{2}$ terhadap $\mathrm{Y}$

\begin{tabular}{|c|c|c|c|c|c|c|}
\hline \multicolumn{7}{|c|}{ ANOVA $^{\mathrm{a}}$} \\
\hline \multicolumn{2}{|r|}{ Model } & Sum of Squares & df & Mean Square & $\mathrm{F}$ & Sig. \\
\hline \multirow{3}{*}{1} & Regression & 1298.337 & 2 & 649.169 & 14.788 & $.000^{\mathrm{b}}$ \\
\hline & Residual & 3511.904 & 80 & 43.899 & & \\
\hline & Total & 4810.241 & 82 & & & \\
\hline & epende & Kemampuan me & is cer & ta pendek & & \\
\hline & dictors: (C & , Penguasaan $\mathrm{k}$ & cata, I & linat baca & & \\
\hline
\end{tabular}

Tabel 3.

Hasil Perhitungan Persamaan Regresi Ganda Variabel $\mathrm{X}_{1}$ dan $\mathrm{X}_{2}$ terhadap $\mathrm{Y}$

\begin{tabular}{|c|c|c|c|c|c|c|}
\hline \multicolumn{7}{|c|}{ Coefficients $^{\mathrm{a}}$} \\
\hline \multirow{2}{*}{\multicolumn{2}{|c|}{ Model }} & \multicolumn{2}{|c|}{$\begin{array}{l}\text { Unstandardized } \\
\text { Coefficients }\end{array}$} & \multirow{2}{*}{$\begin{array}{c}\begin{array}{c}\text { Standardized } \\
\text { Coefficients }\end{array} \\
\text { Beta }\end{array}$} & \multirow[t]{2}{*}{$\mathrm{t}$} & \multirow[t]{2}{*}{ Sig. } \\
\hline & & $\mathrm{B}$ & Std. Error & & & \\
\hline \multirow{3}{*}{1} & (Constant) & 30.151 & 9.193 & & 3.280 & .002 \\
\hline & Minat baca & .333 & .088 & .386 & 3.797 & .000 \\
\hline & $\begin{array}{l}\text { Penguasaan } \\
\text { kosakata }\end{array}$ & .226 & .096 & .240 & 2.364 & .021 \\
\hline
\end{tabular}

Dari tabel 1 juga dapat menjelaskan bahwa secara bersama-sama variabel minat baca dan penguasaan kosakata memberikan kontribusi sebesar $27 \%$ terhadap variabel kemampuan menulis cerita pendek. Dari table 2, dapat dinyatakan bahwa terdapat pengaruh yang signifikan minat baca dan penguasaan kosakata secara bersama-sama terhadap kemampuan menulis cerita pendek. Hal ini dibuktikan dengan perolehan nilai Sig. $0,000<0,05$ dan $F_{h}=14,788$. Sementara itu, persamaan garis regresi ganda dapat dinyatakan dengan $\widehat{Y}=30,151+0,333 \mathrm{X}_{1}+0,226 \mathrm{X}_{2}$. Hal 
ini memiliki pengertian bahwa kenaikan satu skor variabel minat baca dan penguasaan kosakata memberikan kontribusi sebesar 0,333 oleh $\mathrm{x}_{1}$ dan 0,226 oleh $\mathrm{x}_{2}$ terhadap variabel kemampuan menulis cerita pendek. Dari table 3 dapat dinyatakan bahwa terdapat pengaruh yang signifikan minat baca terhadap kemampuan menulis cerita pendek. hal ini dibuktikan dengan perolehan nilai Sig. $0,000<0,05$ dan $t_{h}=3,797$.

Adapun kontribusi variabel minat baca terhadap kemampuan menulis cerita pendek dapat dinyatakan dengan rumus:

$$
\begin{aligned}
& K D=\text { Nilai } \beta_{x 2 y} \times \text { Nilai Korelasi Parsialnya } \\
& \left(r_{x 2 y}\right) \times 100 \% \\
& K D=0,240 \times 0,372 \times 100 \%=8,93 \%
\end{aligned}
$$

Dari hasil perhitungan di atas dapat dinyatakan bahwa kontribusi minat baca dalam meningkatkan kemampuan menulis cerita pendek sebesar 18,06\%.

Dari table 3 dapat dinyatakan bahwa terdapat pengaruh yang signifikan penguasaan kosakata terhadap kemampuan menulis cerita pendek. hal ini dibuktikan dengan perolehan nilai Sig. $0,021<0,05$ dan $t_{h}=2,364$.

Adapun kontribusi variabel penguasaan kosakata terhadap kemampuan menulis cerita pendek dapat dinyatakan dengan rumus:

$K D=$ Nilai $\beta_{x 2 y} \times$ Nilai Korelasi Parsialnya

$\left(r_{x 2 y}\right) \times 100 \%$

$K D=0,240 \times 0,372 \times 100 \%=8,93 \%$

Dari hasil perhitungan di atas dapat dinyatakan bahwa kontribusi penguasaan kosakata dalam meningkatkan kemampuan menulis cerita pendek sebesar $8,93 \%$.

Hasil penelitian di atas menyimpulkan bahwa minat baca dan penguasaan kosakata secara bersama-sama telah memberikan pengaruh positif terhadap kemampuan menulis cerita pendek siswa SMP Swasta di Kabupaten Bogor. Hal ini mengandung arti bahwa minat baca dan penguasaan kosakata telah memberikan pengaruh yang signifikan terhadap peningkatan kemampuan menulis cerita pendek siswa SMP Swasta di Kabupaten Bogor.

Menulis adalah salah satu dari keterampilan bahasa. Untuk menulis diperlukan proses berfikir kreatif. Banyak siswa yang mengalami kesulitan saat mereka diberikan tugas oleh guru Bahasa Indonesia dalam menulis cerita pendek. Hal ini dapat terjadi karena siswa kurang mampu mengembangkan berfikir kreatif, tidak memiliki keterampilan merangkai kalimat, tidak memiliki penguasaan kosakata yang banyak, kurang dapat mengeksplorasi bahasa dan sebagainya. Penguasaan kosakata yang baik akan dapat memberikan kontribusi banyak dalam kegiatan berbahasa, salah satunya penulisan cerita pendek.

\section{SIMPULAN}

Berdasarkan pembahasan di atas dapat disimpulkan bahwa terdapat pengaruh yang signifikan minat baca dan penguasaan kosakata secara bersama-sama terhadap kemampuan menulis cerita pendek siswa SMP Swasta di Kabupaten Bogor.

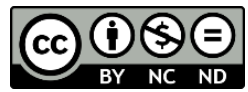

Creative Commons Attribution-NonCommercial-NoDerivatives 4.0 International License 


\section{DAFTAR PUSTAKA}

Depdiknas. (2001). Kamus Besar Bahasa Indonesia. Jakarta: Balai Pustaka.

Kridalaksana, H. (2007). Etimologi-Bahasa Indonesia. Jakarta: Gramedia Pustaka Utama.

Sinaga, A. M., \& Hadiati, S. (2001). Pemberdayaan Sumber Daya Manusia. Jakarta: Lembaga Administrasi Negara.

Nurgiyantoro, B. (2001). Penilaian dalam Pembelajaran Bahasa dan Sastra. Yogyakarta: BPFE.

Nurgiyantoro, B. (2007). Teori Pengkajian. Gajah Mada University Press.

Robin. (2007). Sistem Pengolahan Citra dan Deteksi Wajah pada Sistem Pengenalan Wajah. Laporan Tugas Akhir ITB.

Staehr. (2008). Hubungan Signifikan Keterampilan Berbahasa. Jakarta: Rineka Cipta.

Suparno., \& Yunus. (2004). Keterampilan Dasar Menulis. Jakarta: Universitas Terbuka.

Tarigan, H. G. (2008). Membaca sebagai Suatu Keterampilan Berbahasa. Bandung: Angkasa.

Tarigan, H. G. (2011). Pengajaran Kosakata. Bandung: Angkasa.

Yusdi, M. (2010). Kemampuan Kecakapan. Jakarta: EMK. 